解説

\title{
内陸型地震におけるラドン・エマネーションの挙動 ガンマ線リモートセンシングー—
}

\section{The Behavior of Radon Emanation related to The Inland Earthquake action Gamma Ray Remote Sensing}

\author{
荒木春視*，高田和典**，鎌倉友隆** \\ Harumi ARAKI, Kazunori TAKADA, Tomotaka KAMAKURA
}

目次

\section{1. 地震予知と阪神大地震}

1. 1 直下型地震に見舞われた兵庫県南部地区

1. 2 本震と余震

1. 3 野島地震断層の活動

1. 4 井戸水のラドン濃度観測と直下型地震の予知

2. 大気中のラドン分布とラドン・エマネーション

3 . 大気中のラドン分布と断層活動史

3. 12,300 万年以前の断層（棚倉構造線）

3. 2 160万年以降の活断層 (系静構造線)

3. 32 万年以降の活断層 (仲禅寺断層)

3. 3 1927年の郷村地震断層

3. 4 1948年の福井地震断層

3. 5 1984年の王滝村震源断層

3. 6 1995年の野島地震断層

4. 地上付近のラドン・エマネーション

4. 1 岩石からのラドン・エマネーション

4. 2 断層からのラドン・エマネーション

4. 3 火山噴火地からのラドン・エマネーション

5. ラドン・エマネーションの移動モデル

5. 1 無火山・無地震地域でのラドン移動

5. 2 地款変動域でのラドン移動

5. 3 地震前後におけるラドン移動

6. 淡路島北部でのモデル検証

\section{* 環境地質研究室 (埼玉県所沢市)}

**朝日航洋 (株) 技術センター (埼玉県川越市)

「写真測量とリモートセンシング」Vol. 34, No. 5, 1995
6. 1 検証 1 (本震震源地と大気中のラドン分布)

6. 2 検証 2 (野島地震断層と大気中のラドン分布)

6. 3 検証 3 (断層変位とラドン・エマネーション) 7. $\gamma$ 線リモートセンシングによる地震予知法の提言 参考文献

\section{1. 地震予知と阪神大地震}

\section{1 直下型地震に見舞われた兵庫県南部地区}

淡路島から六甲にかけて密集する活断層は, 日本経 済の動脈である新幹線, 高速道路を横断している。関 東大震災級の地震にも耐えられる筈の土木施設が, こ とごとく打撃を受け, 死傷者は 4 万人を越之, 家屋損 壊も約16万に達した。このような大被害を阪神地区に もたらしたのは，1995年 1 月17日早朝に，明石海峡の 深さ約 $14 \mathrm{~km}$ で発生した M7.2の兵庫県南部地震であ $\eta ， 1948$ 年の福井地震以来の都市直下型地震である。 地震発生から僅か 10 秒間に毎秒 $3 \mathrm{~km}$ の速さで断層は 広がり, 地殻破壊は約 $45 \mathrm{~km}$ の長さに達した。淡路島北

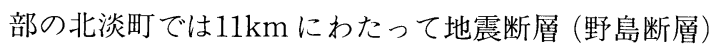
が地上に現れ, 最大で $1.7 \mathrm{~m}$ の横ずれと $1.3 \mathrm{~m}$ の縦ずれ を起こし，変位量は $2.1 \mathrm{~m}$ に達した ${ }^{12)}$ 。

\section{2 本震と余震}

地震で破壊された地層が, 地上に現れたものを地震 断層, 現れなかったものを震源断層と呼んでいる。地 震断層は地震規模が大きく, 震源が比較的に浅い, と 地表に現れる。1984年に王滝村で発生した M6.8の長 野県西部地震では, 地震断層は現れなかったが, この 
ような場合でも震源断層の広がりは余震震源分布から 推定できる。

図 1 は淡路島北部地区における阪神大地震前後の地 震震源分布を示したものである。困 1 の上図には阪神 大地震以前で発生した深さ $30 \mathrm{~km}$ 以浅で, M2 以上の地 震震源分布を示したものである ${ }^{5)}$ 。地震予知の観点か らすれば，帯状に分布する地震帯の中で地震の起きて いない空白域があれば, 将来, 地震の発生する可能性 がある，と注目することになる。困 1 の上网から，野 島断層が近い将来, 震源として活動することを予想す るのは難しい。しかし阪神大地震 M7.2 は起きた。余震 震源地が淡路島北西岸中部から北東へ約 $45 \mathrm{~km}$ にも達 する規模のものであり，それは野島地震断層を出現さ せた

\section{3 野島地震断層の活動}

野島地震断層は阪神大地震で地表に出現する以前か

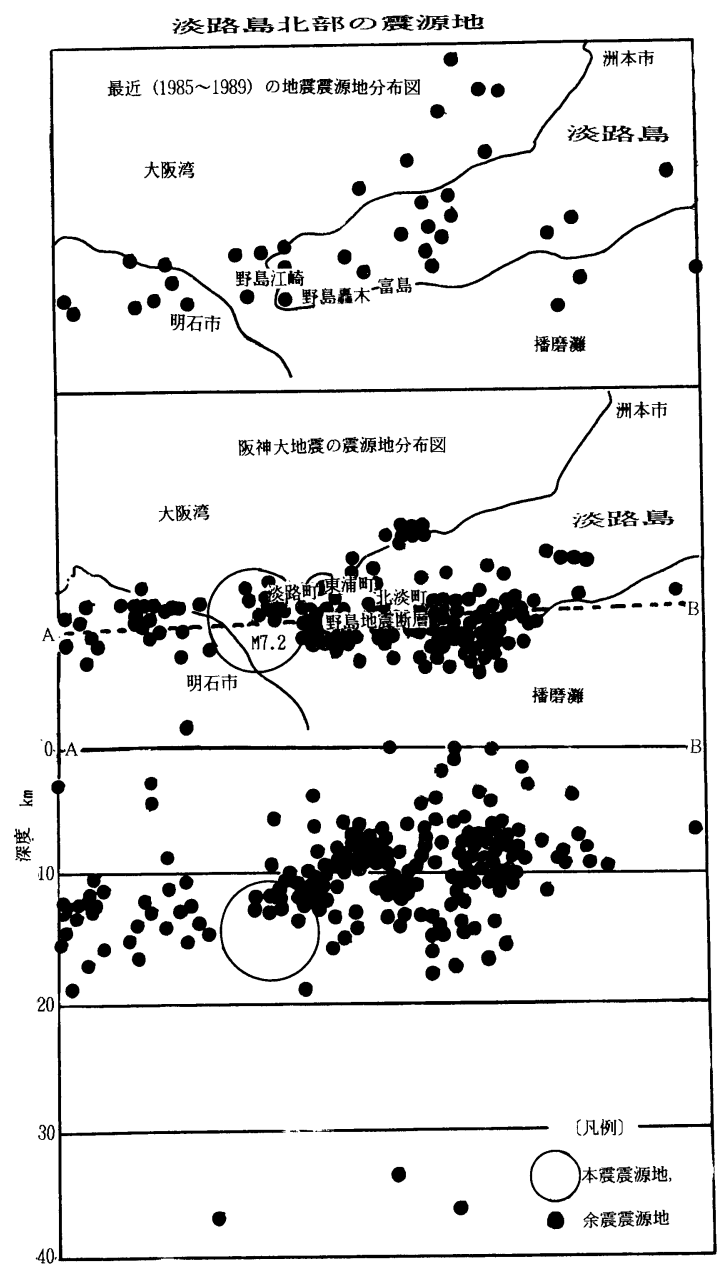

図 1 阪神大地震前後の地震震源地分布図
ら, 航空写真の地形判読で活断層として, その存在が 推测されていた。活断層とは, 過去, だいたい百万年 以内に繰り返し活動し, 今後も活動すると思われる断 層のことで, 地震を引き起こす確率は, 活発なもので も，千年に一回程度である。そのために活断層の活動 の時期を特定するのは，極めて困難なことと考えられ てきた。

阪神大地震では, 淡路島の北淡町で活断層上の民家 の塀が無惨に破壊されたが，横の家は無事だった例も あり，活断層存在に対する危険認識度は人により差が 生じている。しかし, 最近の活動記録のない断層では, 近い将来での地震活動による被害を念頭にいれた, 公 共施設の建設が望まれることになる。

\section{4 井戸水のラドン濃度観測と直下型地震の予知}

地震予知の現代的な課題は科学の視点, 技術の力点 を生命の安全に移すことであり，途中段階の研究デ一 夕を社会が共有し，防災対策に反映させていく努力で ある，と考える。

地震予知は従来の地震学・測地学的手法に加之, 電 磁気学や地球化学等を応用し, 総合的, かつ学際的に 進めなければならない時代にきている。

阪神大地震では, 発生に先だつ50分前に超長波の異 常電波が捕らえられている。際だった地震前兆として は, 西宮市の深さ $17 \mathrm{~m}$ の井戸で, 水中ラドン濃度の激 増が観測されている。困 2 は阪神大地震発生前後にお ける井戸水ラドン濃度変動を示したものである ${ }^{10)}$ 。観 測は地震発生の約 3 力月前から開始され，それ以降， 水中ラドン濃度は不規則なサイクルの中で漸増し，地 震発生 8 日前には過大な増加を示した。以降, 急激な 減少を続けて地震発生に至っている。地震発生以降の 水中ラドン濃度は 3 ケ月前のものよりも低下してい る。

水中ラドン濃度の増加現象が $17 \mathrm{~m}$ の浅井戸で地震 発生の 3 ケ月前から見られたことは, 地壳破壊が 3 力

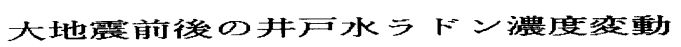
危険期間

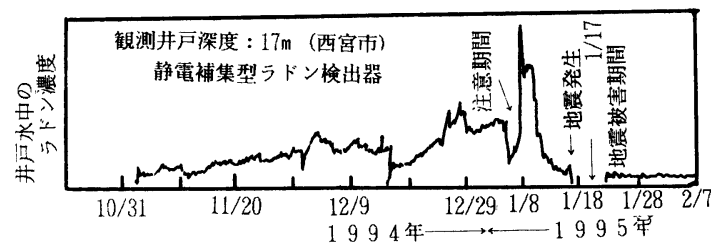

図 2 阪神大地震発生前後の井戸水ラドン濃度変動（佐伯 ほか ${ }^{10)}$ に加筆) 
月以前から進行し，破壊に合わせてラドンの地中移 動・上昇が起きていたことを示している。そして，こ の地款破壊は，ノイズ並の低エネルギーであったため に，通常デー夕に埋没し，前兆現象として捕らえられ なかった，と推測される。

\section{2.大気中のラドン分布とラドン・エマネー ション}

\section{1 エアボーン $\gamma$ 線スペクトロメトリ}

ヘリコプターに $1,608 \mathrm{~cm}^{3} の ヨ ウ$ ウ化ナトリウム結晶 を 8 個積み, 高度 100 - $150 \mathrm{~m}$ から 0.5 秒間の環境 $\gamma$ 線 をマルチチャンネル型波高分析器を介して, 所定の工 ネルギー带域の放射線量を高度と共に連続記録する。 観測成分とエネルギー帯域は以下の通りである。なお， 観測飛行を時速 $90 \mathrm{~km}$ で実施した場合，空間分解能は $12.5 \mathrm{~m}$ である。

なお，観測 $\gamma$ 線成分のビスマス ${ }^{214} \mathrm{Bi}$ はラドン同位 元素のラドン ${ }^{222} \mathrm{Rn}$ (半減期 3.82 日) から, 夕リウム 208

\begin{tabular}{|c|c|c|}
\hline $\begin{array}{c}\text { チャネル } \\
\text { No. }\end{array}$ & $\begin{array}{c}\text { エネルギー帯域 } \\
\mathrm{MeV}\end{array}$ & 観測 $\gamma$ 線成分 \\
\hline Ch1 & $0.50 \sim 0.08$ & $\begin{array}{l}\text { ビスマス }{ }^{214} \mathrm{Bi} \\
\text { 夕リウム }{ }^{208} \mathrm{~T} 1 \\
\text { 散乱 } \gamma \text { 線 }\end{array}$ \\
\hline Ch2 & $1.30 \sim 1.60$ & カリウム ${ }^{40} \mathrm{~K}$ \\
\hline $\mathrm{Ch} 3$ & $1.60 \sim 2.00$ & ビスマス ${ }^{214} \mathrm{Bi}$ \\
\hline $\mathrm{Ch} 4$ & $2.40 \sim 2.80$ & タリウムム ${ }^{208} \mathrm{~T} 1$ \\
\hline $\mathrm{Ch} 5$ & $0.15 \sim 3.00$ & 全環境 $\gamma$ 線 \\
\hline
\end{tabular}

$\mathrm{T} 1$ はラドン同位元素のトロン ${ }^{220} \mathrm{Rn}$ (半減期55.6秒) か ら生成される。ここでガンマ線スペクトロメトリでは Ch1 を散乱 $\gamma$ 線成分 $\left(\gamma^{\prime}\right)$, Ch2 をカリウム成分 $(\mathrm{K})$, $\mathrm{Ch} 3$ をラドン成分 $(\mathrm{Rn}), \mathrm{Ch} 4$ をトロン成分 $(\mathrm{Tn}), \mathrm{Ch} 5$ を環境 $\gamma$ 線成分 $(\gamma)$ と呼称することにする。

\section{2 大気中のラドン分布}

エアボーン $\gamma$ 線スペクトロメトリで観測される環 境 $\gamma$ 線には, 地殼と大気からのものとがある。地款か らの $\gamma$ 線としては, カリウム ${ }^{40} \mathrm{~K}$, ビスマス ${ }^{214} \mathrm{Bi}$, タリ ウム ${ }^{208} \mathrm{Tl}$ があり，これらは岩石・鉱物中のカリウム ${ }^{40}$ $\mathrm{K}$ とラドン元素 $\left({ }^{222} \mathrm{Rn},{ }^{220} \mathrm{Rn}\right)$ に起源を持つ。また大 気からの $\gamma$ 線としてはビスマス ${ }^{214} \mathrm{Bi}$ ，タリウム ${ }^{208} \mathrm{~T} 1$ があり，これらは大気中に浮遊するラドン元素 $(222$ $\mathrm{Rn},{ }^{220} \mathrm{Rn}$ ) に起源を持つ。従って地殸起源の $\gamma$ 線は力
リウム ${ }^{40} \mathrm{~K}$ と深い関係にあり, 大気起源の $\gamma$ 線はカリ ウ ${ }^{40} \mathrm{~K}$ と無関係に存在していることになる。これら の関係を数式で示すと次のようになる。

$$
\begin{aligned}
& \mathrm{K}=\mathrm{K}(2) \\
& \mathrm{Rn}=\mathrm{Rn}(1)+\mathrm{Rn}(2)
\end{aligned}
$$$$
\text { また }
$$$$
\mathrm{Rn}(2)=\mathrm{aK}(2)+\mathrm{B}
$$

但し, $\mathrm{K}$ : エアボーン $\gamma$ 線調査で空中観測された

$$
\text { カリウム }{ }^{40} \mathrm{~K}
$$

$\mathrm{Rn}$ : エアボーン $\gamma$ 線調査で空中観測され たビスマス ${ }^{214} \mathrm{Bi}$ ，またはタリウム ${ }^{208} \mathrm{Tl}$

$\mathrm{a}$ ：地質・岩質で変わる係数

B：地域で決まる常数

（1）：大気起源

（2）：地款起源

即ち, 大気中のラドン分布は大気起源のラドン $\mathrm{Rn}$

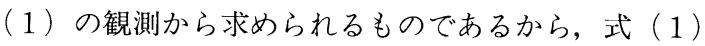
$\sim(3)$ から

$$
\mathrm{Rn}=\mathrm{Rn}(1)+\mathrm{aK}(2)+\mathrm{B}
$$

更に，エアボーン $\gamma$ 線調査における空中観測では，

$\mathrm{Rn}(1)>>\mathrm{B}$ と仮定すれば

$$
\mathrm{Rn}=\mathrm{Rn}(1)+\mathrm{aK}(2)
$$

となる。エアボーン $\gamma$ 線調查の観測結果からラドン $\mathrm{R}$ $\mathrm{n}$ とカリウム $\mathrm{K}$ との一次回帰式

$$
\mathrm{Rn}=\mathrm{aK}(2)+\mathrm{b}
$$

を求めれば，大気中のラドン分布 Rn（1）は

$$
\mathrm{Rn}(1)=\mathrm{b}
$$

として知ることができる。

\section{3 ラドン・エマノメトリ}

マグマから生成された地殼の新鮮な岩石にはカリウ $ム^{40} \mathrm{~K}$ ，ウラン ${ }^{238} \mathrm{U}$ ，トリウム ${ }^{232} \mathrm{Th}$ ，と言った放射性元 素が一定の割合で含まれ，その割合は岩質の違いで大 きく変わらない。これらの元素では，その後の地質学 的な時間経過と共に放射性壊変が進行し，ラドン同位 元素のラドン ${ }^{222} \mathrm{Rn}, \quad ト ロ ン{ }^{220} \mathrm{Tn}$ を経て鉛元素へと変 わっていく。これらのラドン同位元素は不活性の気体 であり，一部はラドン・エマネーションとして，地殼 変動や続成作用を受けて岩石から飛び出し, 亀裂を伝 わって大気中, あるいは地下水中に溶解し, 地層中を 移動する。ラドン・エマネーションを大気中や地層中 へ送り出すポンプの役割りを担うのが, 潮汐作用であ り, 地下水位鼓動, そして気温・気圧の変動である。 これらの関係を数式で示すと次のようになる。 
$\mathrm{Rn}(0)=\mathrm{a}_{0} \mathrm{~K}(0)+\mathrm{B}_{0}$

地殼変動, 続成作用により

$\mathrm{Rn}(0)=\mathrm{Rn}+\Delta \mathrm{Rn} \uparrow$

また

$\mathrm{K}(0)=\mathrm{K}+\Delta \mathrm{Ar} \uparrow$

但し， $\mathrm{K}$ : エアボーン $\gamma$ 線調査で空中観測される カリウム ${ }^{40} \mathrm{~K}$

$\mathrm{Rn}$ ：エアボーン $\gamma$ 線調査で空中観測され るビスマス ${ }^{214} \mathrm{Bi}$ ，または夕リウムム ${ }^{208} \mathrm{Tl}$

$\mathrm{a}_{0}$ : 岩質で変わる係数

$\mathrm{B}_{0}$ : 地域で決まる常数

$\Delta \mathrm{Rn} \uparrow:$ 飛び出したラドン・エマネーション

$\Delta \mathrm{A} r \uparrow:$ 飛び出したアルゴン

(0)：マグマ起源

即ち, ラドン・エマネーションは創成期の岩石中の ラドンと現地調查で観測されたラドンの差として, 求 められるものであるから，式（8）～(10) から

$\Delta \mathrm{Rn} \uparrow=\mathrm{a}_{0} \mathrm{~K}+\mathrm{a}_{0} \Delta \mathrm{Ar} \uparrow+\mathrm{B}_{0}-\mathrm{Rn}$

ここで， $\Delta \mathrm{A} \mathrm{r}$ は観測センサに補足されないので, $\mathrm{a}_{0} \Delta \mathrm{Ar}=0$ とみなすことができ，（11）式は

$\Delta \mathrm{Rn} \uparrow=\mathrm{a}_{0} \mathrm{~K}+\mathrm{B}_{0}-\mathrm{Rn}$

となる。なお，係数 $\mathrm{a}_{0}$ 及び常数 $\mathrm{B}_{0}$ には，第四紀火山で マグマから生成された新鮮な岩石の分布する地域を選 定して $\gamma$ 線スペクトロメトリを実施し，その観測結果 からラドン Rn とカリウム $\mathrm{K}$ との一次回帰式

$$
\mathrm{Rn}=\mathrm{a}_{0} \mathrm{~K}+\mathrm{B}_{0}
$$

を求め, ここでの $\mathrm{a}_{0}$ 及び $\mathrm{B}_{0}$ の值を使用すればよい。

従って, 観測地のラドン・エマネーション $\Delta \mathrm{Rn}$ は, 観測地のカリウム $\mathrm{K}$ 值とラドン $\mathrm{Rn}\left(\right.$ ビスマス ${ }^{214} \mathrm{Bi}$ ，ま たはタリウム ${ }^{208} \mathrm{Tl}$ ）值を（12）式に代入すれば，求め ることができる。

\section{3. 大気中のラドン分布と断層活動史}

\section{$3.12,300$ 万年以前の断層（棚倉構造線）}

八溝山脈 (堆積岩が主体) と阿武隈山地（変成岩類· 花崗岩類が主体）との間には，北北西一南南東方向に 走る，幅数 $\mathrm{km}$ の大きな断層破砕帯が存在する。この 破砕带は中生代白亜紀から新第三紀にかけて活動した 断層運動の名残りであって, 現在は静穞な状態にある。

図 3 に活動史の異なる地質構造線上空でのラドン分 布を示す。図 3 によると，棚倉構造線では

1）散乱 $\gamma$ 線成分が, 180 と特に少なく,カリウム成 $-52-$

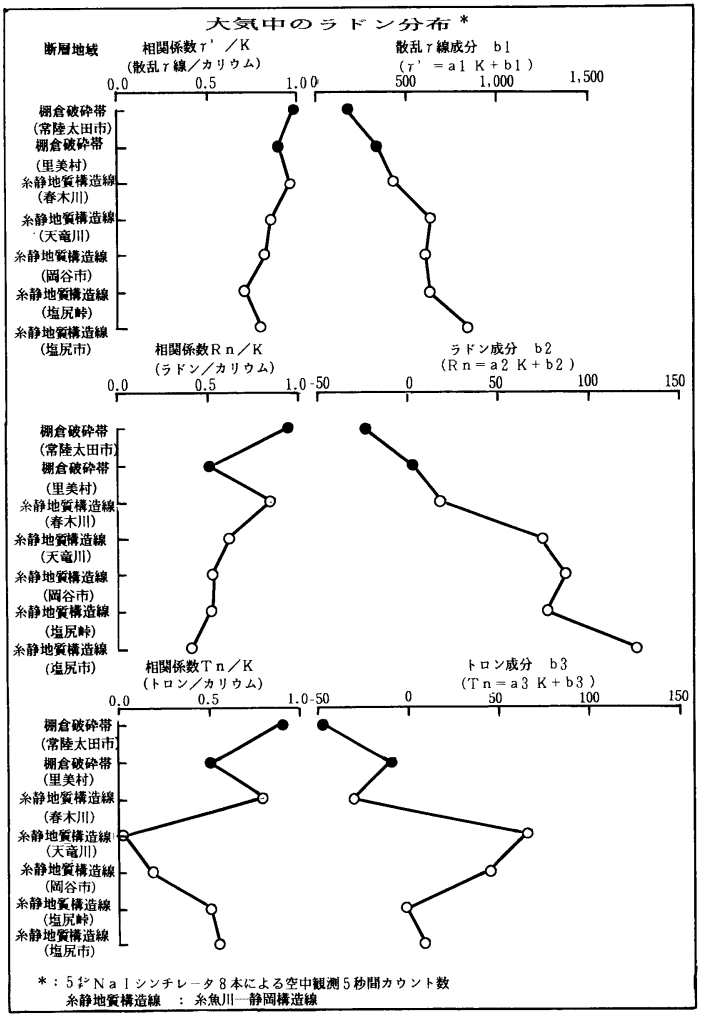

図 3 活動史の異なる地質構造線上空でのラドン分布

分との相関係数が， 0.97 と, 格別，高い

2 ）ラドン成分が, -22 と格別に少なく,カリウム成 分との相関係数が，0.95と，格別，高い

3 ）トロン成分が, -47 と格別に少なく,カリウム成 分との相関係数が, 0.90 と, 格別, 高い

従って,棚倉構造線上空でのラドン分布を総括すると， 上空の浮遊ラドンが特に少なく，また，地上ではラド ン元素がカリウム成分と, 格別, 高い相関性を維持し ており, 地款が格別に安定している, と推測され る。

\subsection{0 万年以降の断層（糸魚川一静岡構造線）}

本州を横断する糸魚川－静岡構造線はM $7 \sim 8$ 級の 大地震を発生させる能力のある大きな活断層である。 被害地震は松本以北では知られているが, 松本以南で の記録はない。しかし古代から縄文時代に諏訪周辺で 大地震の起きた証拠が残っており，過去の約8000年間 に少なくても 3 回以上, 大地震は起きている。最新の 地震は, $1000 ２ 000$ 年以前に発生している ${ }^{3)}$ 。諏訪盆地 の凹地形は，諏訪湖を挟んで両側に断層が通り，その 間の土地の陥没で形成されたものである。この断層が 
糸魚川ー静岡構造線である。

図 3 の活動史の異なる地質構造線上空でのラドン分 布を見ると，糸魚川一静岡構造線では

1) 散乱 $\gamma$ 線成分が, 塩尻市地内では, 845 と特に多 く，カリウム成分との相関係数も 0.80 と高い

2 ） ラドン成分が, 塩尻市地内では 127 と多く, カリ ウム成分との相関係数は，0.41と低い

3 ）トロン成分が，岡谷市の天竜川よりで，66と多 く, カリウム成分との相関係数が 0.03 と, 特別, 低い

従って，糸魚川ー静岡構造線上空でのラドン分布を総 括すると, 塩尻市地内では上空の浮遊ラドンが多い。, 地上でのラドン元素とカリウム成分との相関性はやや 低くなるが，地殼は比較的に安定している，と推測さ れる。なお，岡谷市の天竜川よりでは，表層の地質が 格別に乱れている。

\subsection{7年の郷村地震断層（北丹後地震）}

山院の沿岸地域には過去の大地震の証拠になる明確 な活断層がほとんど認められない。そのような地域で 1872年の浜田地震 M7.1 以降, 1943年鳥取地震 M7.2 ま での71年間に但馬地震 M6.8，1927年北丹後地震 M7.3 等の直下型大地震が連続して 4 件も発生している3)。 古い過去の地震で, 地表まで到達しなかった震源断層 か, もしくは侵食と堆積で断層地形が隐されてしまっ のたか，そんな伏在断層が地中にあったのかもしれな い。

図 4 に各地震断層上空におけるラドン分布につい て，比較した結果を示す。困 4 によると，郷村地震断 層では,

1 ）散乱 $\gamma$ 線成分が，1196と異常に多く，カリウム 成分との相関係数は 0.69 と, やや低い

2 ） ラドン成分が, 212 と異常に多く, カリウム成分 との相関係数は 0.19 と, 特に低い

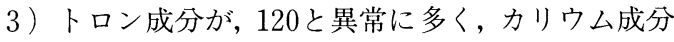
との相関係数は 0.22 と, 特に低い

$4 ）$ ラドン分布において，本震震源地から遠ざかる のにつれて, 3 成分とも, ラドン量が減少し, カリウム成分との相関係数が増加する

従って, 郷村地震断層上空でのラドン分布を総括する と, 本震震源地の上空では浮遊ラドンが異常に多く, また，地上のラドン元素とカリウム成分との相関性は 特に悪い状態にあって，地殻が未だ安定な状態に戻っ ていない, と推測される。しかし本震震源地から離れ
るのにつれて, 地款が急速に安定な状態に移り変わっ ている。

\subsection{8年の福井地震断層（福井地震）}

日本海側の福井平野の中心的な都市, 福井市。その 近郊を震源地とした M7.1の都市直下型の地震が福井 地震である。その時，死者は 3848 人にのぼった。福井 地震断層は延長が約 $25 \mathrm{k} \mathrm{m}$ である。なお福井地震断層 は南南東に根尾谷断層，柳ヶ瀬断層と続く，大きな破 砕带を伴う福井・根尾谷ブロックの一員でもある。

図 4 の地震断層上空におけるラドン分布比較図によ ると, 福井地震断層では

1）散乱 $\gamma$ 線成分が，1093と異常に多く，カリウム 成分との相関係数は 0.64 , とやや低い

2 ）ラドン成分が，164と異常に多く，カリウム成分 との相関係数は 0.34 , と低い

$3 ）$ トロン成分が，111と異常に多く，カリウム成分 との相関係数は 0.20 と特に低い

4 ） ラドン分布において，本震震源地から遠ざかる のにつれて，3成分とも，ラドン量が減少し， カリウム成分との相関係数が増加する

従って, 福井地震断層上空でのラドン分布を総括する と, 本震震源地の上空では浮遊ラドンが異常に多く, また，地上のラドン元素とカリウム成分との相関性は 特に悪い状態にあって，地殼が未だ安定な状態に戻っ ていない, と推測される。しかし本震震源地から離れ るのにつれて, 地款が急速に安定な状態に移り変わっ ている。

\subsection{4年の王滝村震源断層（長野県西部地震）}

地震が小規模であったり, 震源が深いと, 地表に地 震断層が現れない。M 7 未満の地震では地震断層の地 表に現れないことも少なくない。御岳山腹の大崩壊が 3600 万 $\mathrm{m}^{3}$ の岩屑流となって山麓に被害を与えた M6.8 の長野県西部地震でも震源断層は地表に届かなかっ だ)。

図 4 の地震断層上空におけるラドン分布比較図によ ると，王滝村震源断層では

1) 散乱 $\gamma$ 線成分が，676と多いが，カリウム成分と の相関係数は 0.91 と, 格別, 高い

2）ラドン成分が，82と少なく，カリウム成分との 相関係数は 0.79 と, 高い

$3 ）$ トロン成分が, 30 と, 少ないのに, カリウム成 分との相関係数は 0.58 , やや低い

4 ） ラドン分布において, 本震震源地から遠ざかる 
のにつれて， 3 成分とも，ラドン量が減少し， カリウム成分との相関係数が散乱 $\gamma$ 線成分と ラドン成分では僅かに，トロン成分ではやや大 きく増加する

従って, 王滝村震源断層上空でのラドン分布を総括す る本震震源地の上空では浮遊ラドンが少なく, また, 地上のラドン元素とカリウム成分との相関性は地款で は良いものの, 表層では少々, 悪い状態にある。地殼 は安定な状態にあるものの, 表層では未だ十分な安定 状態にない, と推測される。しかし本震震源地から離 れるのにつれて, 表層も急速に安定な状態に移り変 わっている。

\subsection{5年の野島地震断層（兵庫県南部地震）}

六甲山麓から明石海陝の震央を経て淡路島北部にか け, 活断層 (六甲断層系) が発達している。淡路島北 淡町の野島江崎から直線状に小倉まで伸びる延長約 7 $\mathrm{km}$ の活断層が野島断層であり, 兵庫県南部地震では, この断層が動いている。野島断層の活動度を $1 \mathrm{~m} / 10^{3}$ 年 の変位量とすると, 活動再来期間は約 2 千年になる ${ }^{12)}$ 。

図 4 の地震断層上空におけるラドン分布比較図によ ると, 野島地震断層では

1) 散乱 $\gamma$ 線成分が, 808 と, 特に多く, カリウム成 分との相関係数は 0.24 と, 特に低い

2 ） ラドン成分が，83と，少ないのに，カリウム成 分との相関係数は 0.10 と, 特に低い

3 ）トロン成分が, 88 と, 特に多く, カリウム成分 との相関係数は-0.18と, 格別, 低い

$4 ）$ ラドン分布において, 本震震源地から遠ざかる と, 3 成分とも, ラドン量が減少し, カリウム 成分との相関係数が激増する

従って, 野島地震断層上空でのラドン分布を総括する と, 本震震源地の上空では浮遊ラドンのうち, ラドン 成分 ${ }^{222} \mathrm{Rn}$ が少なく，トロン成分 ${ }^{220} \mathrm{Rn}$ が多くなってい る。また, 地上のラドン元素とカリウム成分との相関 性は特に低く, 表層では格別に悪い状態になっている。 地殼は不安定な状態に, 表層では一層, 不安定状態に ある，と推測される。しかし本震震源地から離れるの につれて, 安定な状態に移り変わっていくが, それも 表層で，やや顕著に進行する。

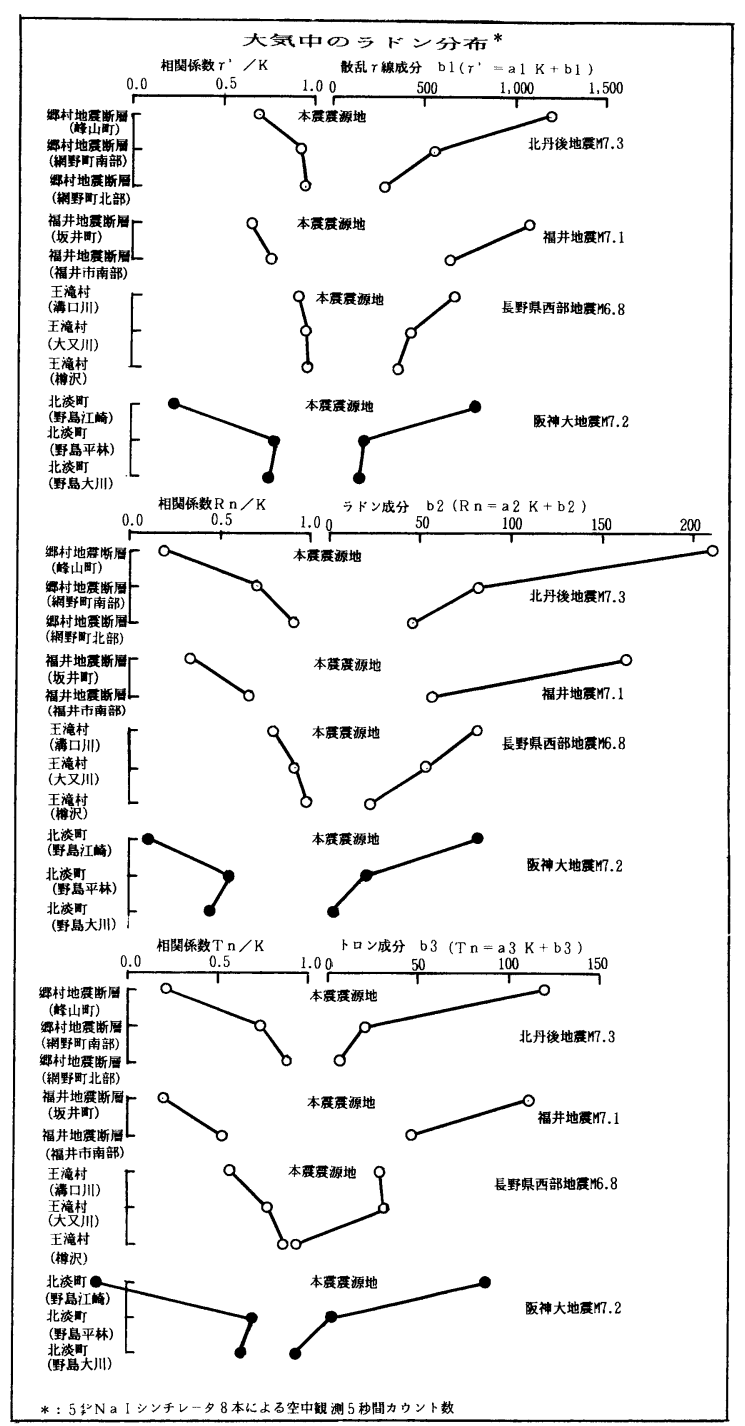

図 4 地震断層上空におけるラドン分布比較

\section{4. 地上付近のラドン・エマネーション}

\section{1 岩石からのラドン・エマネーション}

岩石にはウラン ${ }^{238} \mathrm{U}, \quad$ トリウム ${ }^{232} \mathrm{Th}$, カリウム ${ }^{40} \mathrm{~K}$ が含まれ, 各元素の半減期は $4,498 \mathrm{my}, 13,900 \mathrm{my}$, $11,850 \mathrm{my}$ で, それぞれが鉛 ${ }^{206} \mathrm{~Pb}$, 鉛 ${ }^{208} \mathrm{~Pb}$, アルゴン ${ }^{40}$ $\operatorname{Ar}$ に壊変する。これら各元素の壊変過程で生成される

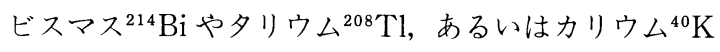
からガンマ線が放出され, 放射性壊変は, 一層, 進行 する。地質時間の経過につれて, これらの放射性元素 は岩石から減少することになる。 
ここで, 地殸変動に遭遇した岩石にあっては，ビス マス ${ }^{214} \mathrm{Bi}$, タリウム ${ }^{208} \mathrm{~T} 1$ の親核種であり，かつ気体元

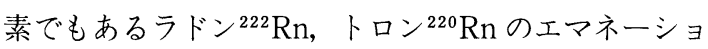
ン化が起こる。即ち地殼変動が原因で岩石・鉱物中に 歪み, 亀裂, 風化, 変質等が発生すると, エマネーショ ン化したラドンは母岩・原岩から移動し，一部が間隙 水に溶解したり，粘土鉱物に収着されるものの，大気 中にまで到達し, 浮遊ラドンとなる。地款変動に遭遇 する頻度の多い古期岩石地域においては, 浮遊ラドン は新期岩石地域よりも多くなる。

図 5 にラドンエマノメータ(応用光研工業：福生市) により地上で観測された，地域の岩質とラドン・エマ ネーション量（2 インチ NaI シンチレータによる観 測）の関係を示す。困 5 によると

1) ラドンエマノメータの使用により, 各種岩石か ら，ラドン・エマネーションの成分を分離観測 できた

2 ) 活断層地域では, 岩質と無関係に, 散乱 $\gamma$ 線成

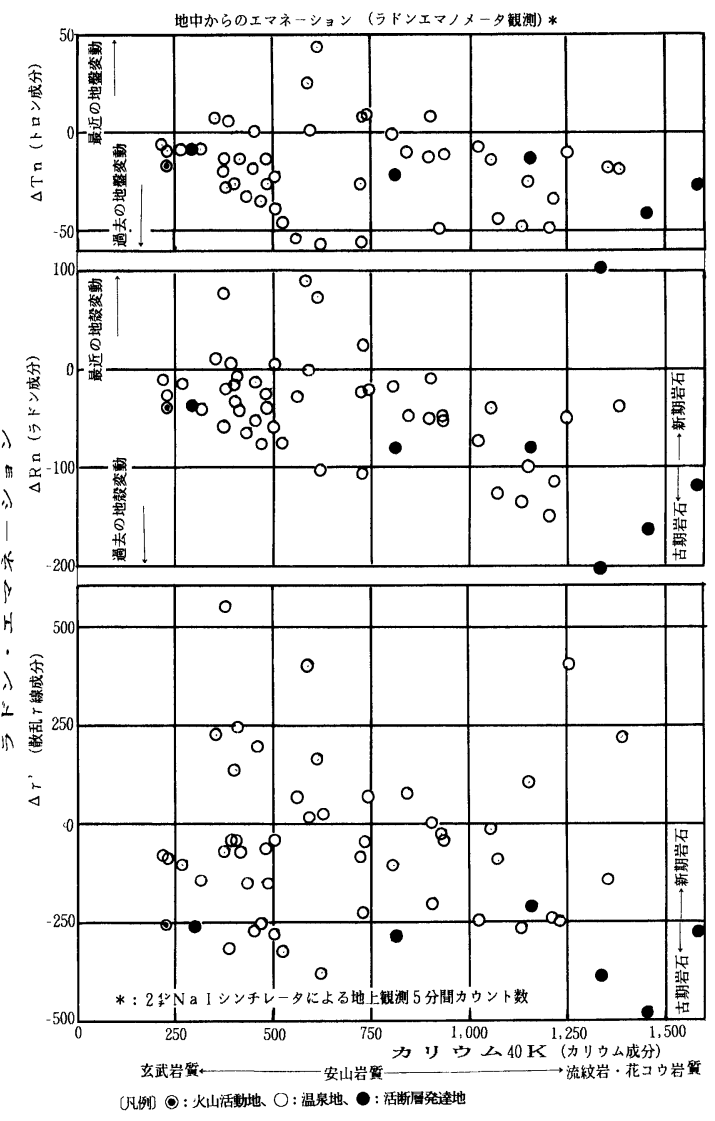

図 5 地中からの移動ラドン・エマネーション量と岩質
分 $\Delta \gamma^{\prime}$, ラドン成分 $\Delta \mathrm{Rn}$ が少なくなっている

3 ）温泉地域は, 比較的に新期の安山岩類のうち,

過去に地殼変動を受けているものの，近年にお いて地盤変動の少ない地域に存在している

4) 火山活動地域ではラドン・エマネーションが少 なく, 特に, 散乱 $\gamma$ 線成分 $\Delta \gamma^{\prime}$ の逸失が目立つ 従って, 岩石からのラドン・エマネーションについて 総括すると, 活断層地域では地殼変動でラドン・エマ ネーションの逸失が起きており, 温泉地域では過去の 地殻変動でラドン・エマネーションの一部が逸失して いるものの，近年の地盤変動が少なく，一層の逸失は 抑制されている。また火山活動地域では散乱 $\gamma$ 線成分 の逸失が多くなっている。

\section{2 断層からのラドン・エマネーション}

繰り返し活動した断層面は圧砕され，断層粘土や断 層破砕帯ができる。断層は地殻内情報を地上にもたら す伝達機能を持っている。その際の情報媒体がラド ン・エマネーションである。ラドン・エマネーション は不活性気体であり，水のような流体と違って，小さ な陌間や亀裂でも浸入でき，移動できる。そんな性質 からラドン・エマネーションは地層の間隙水圧や粒子 間応力の時間的な変化をリアルタイムで把握し, 情報 媒体となって，地上に伝達する特性を持っている。

活断層地域のラドン・エマネーション量は周辺地域 と比較して, 平常時にあっては, 少ない。しかし断層 が活動すると,断層面を伝わってラドン・エマネーショ ンの顕著な移動が起きる。それも断層運動の規模が大 きなほど，移動するラドン・エマネーションも多くな る。

図 6 にラドン・エマノメータで観測された，地震断 層・活断層付近から放出されるラドン・エマネーショ ンを，成分相関図 $\left(\Delta y^{\prime} / \Delta \mathrm{Rn} / \Delta \mathrm{Tn}\right)$ にして示す。困 6 によると

1 ）地震断層のラドン成分 $\Delta \mathrm{Rn}$ は活断層と較べ, 等価の散乱 $\gamma$ 線成分, もしくは等価のトロン成 分において，明らかに大きくなっている

2 ) 最大横ずれが $1.7 \mathrm{~m}$ の野島地震断層 (M7.2) と $0.5 \mathrm{~m}$ 石廊崎地震断層 (M6.9) を比較するとき, 等価ラドン成分において, 野島地震断層の散乱 $\gamma$ 線成分，トロン成分が大きく，トロン成分に あっては差が大きなもになっている

3 ）郷村地震断層と, 近接する仲禅寺断層との比較 では，ラドン成分において明らかに地震断層で 


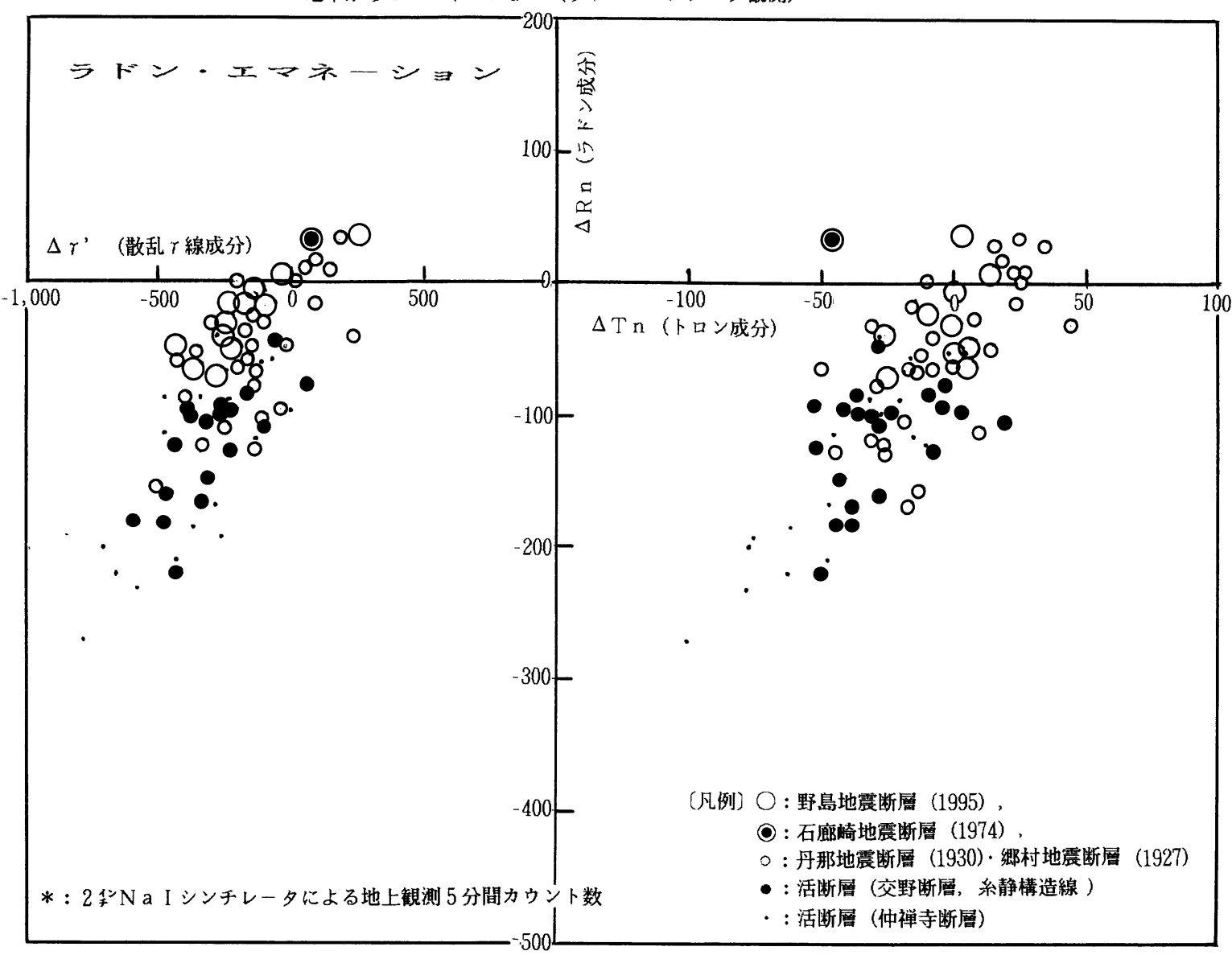

図 6 地震断層・活断層付近から放出されるラドン・エマネーション

大きくなっているものの, 分布の重なるものも 存在する

従って，断層からのラドン・エマネーションを総括す ると, 地震断層においてはラドン成分が活断層でより も多くなり，また地上変位の大きなものにあっては， トロン成分まで一段と多くなる。

\section{3 火山噴火地からのラドン・エマネーション}

火山活動で噴出されるマグマでは放射性核種の壊変 は未だ進んでいないので, ラドン・エマネーションも ゼロに近い。しかし山体には既に放射性壊変の進んで いる岩石が広く分布している。上昇するマグマ火道周 辺の地下水は高温高圧の水蒸気と化し, 山体岩石の間 隙まで埋めつくしている。そこを通る散乱 $\gamma$ 線成分は 吸収される。

四 7 にラドン・エマノメータで観測された, 噴火口・
温泉地から放出されるラドン・エマネーションを成分 相関図 $\left(\Delta \gamma^{\prime} / \Delta \mathrm{Rn} / \Delta \mathrm{Tn}\right)$ にして示す。図 7 によると

1) 噴火口の散乱 $\gamma$ 線 $\Delta \gamma^{\prime}$ は温泉源泉と較べ，等価 ラドン成分において，明らかに小さくなってい る

2 ）噴火口にあっては, 各成分 $\left(\Delta \gamma^{\prime}, \Delta \mathrm{Rn}, \Delta \mathrm{Tn}\right)$ とも負值で，ゼロ周辺に集合している

従って, 火山噴火地のからのラドン・エマネーション を総括すると，噴火口にあっては，各成分ともゼロに 近い負值を示し, 温泉源泉との比較では散乱 $\gamma$ 線成分 が明らかに少なくなっており，上述のような状況を裏 付けている。 


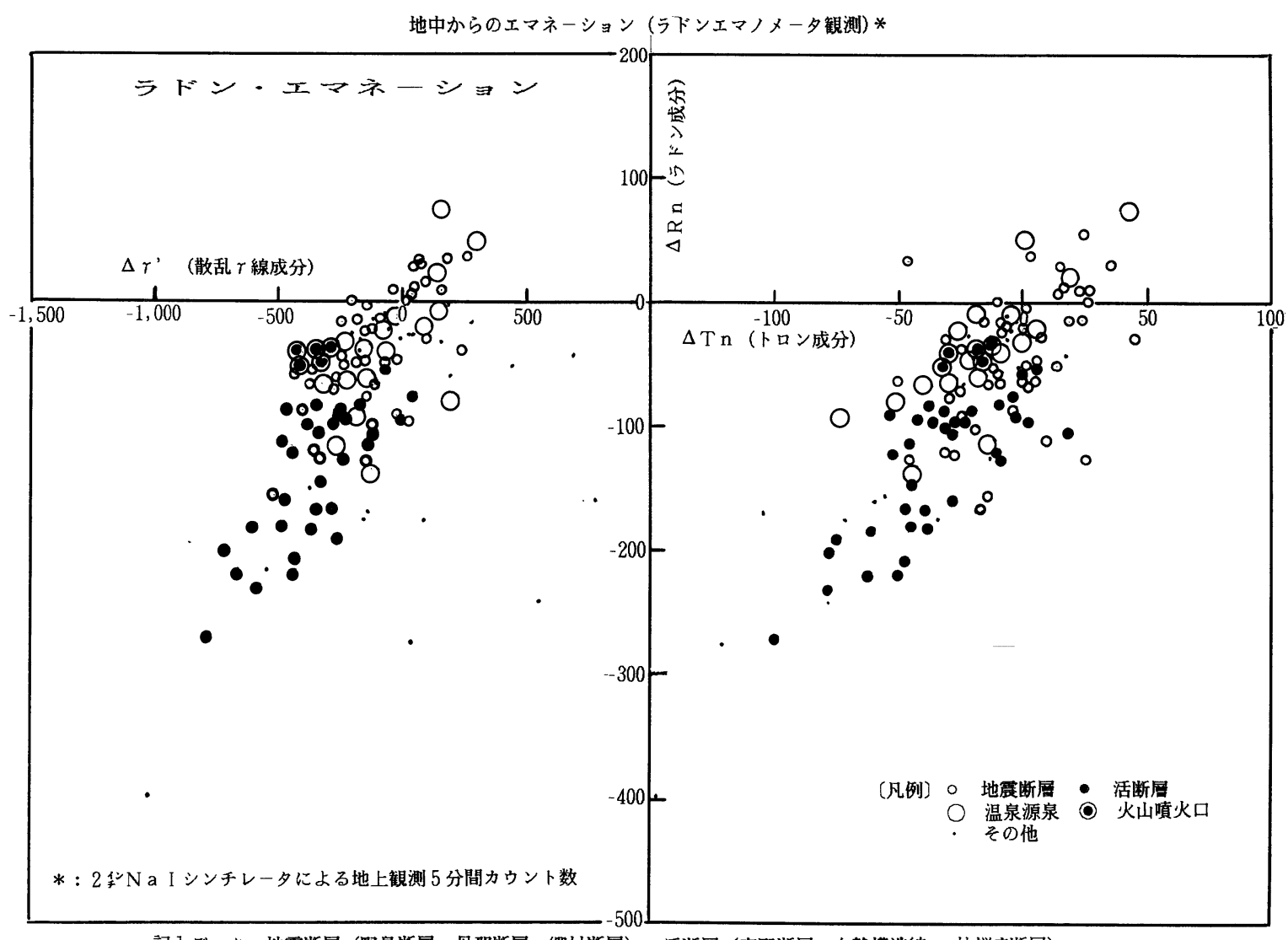

記入デー夕：地震断層（野島断居，丹那断居，鄉村断居），活断層（交野断層，系静構造線，仲禅寺断層）

温泉 (北海道十勝岳、上信越、北陸、日光、伊豆半島)，火山 (三宅島)， その他 (周辺地域)

図 7 噴火ロ・温泉地から放出されるラドン・エマネーション

\section{5. ラドン・エマネーションの移動モデル}

\section{1 無火山・無地震地域でのラドン移動}

火山活動もなければ, 被害地震もない, そんな地域 では地款も，地盤も安定している。地中歪みの大きな 蓄積も，地層間隙水圧の異常な増大も，ない。そのた めに岩石・鉱物中の空隙も，ごく僅かで, ラドンがエ マネーション化して鉱物から抜け出し, 移動すること は容易でない。その結果, 無火山・無地震地域上空に 浮遊する大気中のラドンは少ない。一方，地殻変動の 少ない地上では，ラドンがカリウム成分と，高い相関 性を持ち，一体となって存在する。

図 8 は無地震・無火山帯と地震火山帯について, 大 気中に浮遊するラドンを，比較したものである。この 図から
1）無火山・無地震带では大気中のラドンが少なく なっている

2）火山・地震帯で，ラドン成分にあっては，特に 多くなっている

3）地上における各成分とカリウム成分との相関性 においては，火山・地震帯で低くなっている。 特にトロン成分にあって，格別低い相関を示す 地区では，有史前の大規模地滑り跡が発見され ており，地盤に乱れが存在する

ことが明らかで, 上述の推論の正しさが裏付けられて いる。

\section{2 地殻変動域でのラドン移動}

地震活動では本震に始まり, 余震域が活動断層面に 沿って広がる。本震震源地では大きな地殼変動が起こ り, 岩石・鉱物中に間隙, 亀裂が形成される。そこに は水分子が通れなくても, 不活性気体元素ラドンの通 


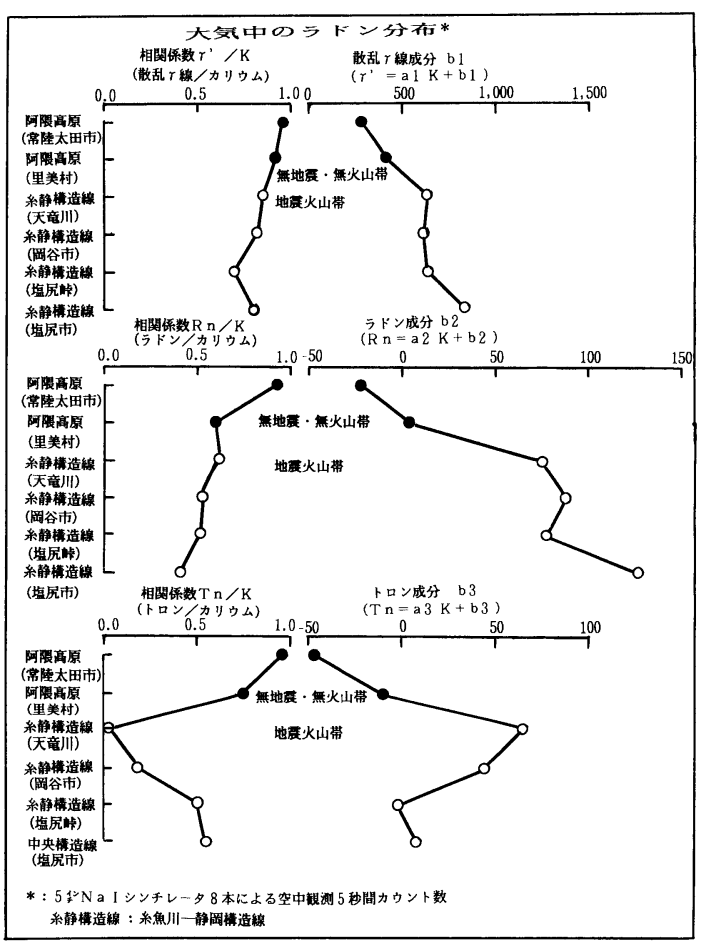

図 8 上空ラドン分布の無地震・無火山帯と地震火山帯で の比較

れる狭いものもある。地款変動で岩石・鉱物からエマ ネーション化したラドンの中には，地中を上昇し，大 気中にまで到達するものもある。地殼変動の大きな本 震震源地に近い地域ほど, 大気中に放出されるラドン は多くなる。地中から上昇してきたラドンには表層で
捕獲されるものもある。地上ではカリウム成分と母岩 を異にするラドンも出現し，ラドンとカリウム成分の 相関性が乱れる。それが負相関にまで悪化することも ある。しかし，本震震源地から離れ，地殼変動が少な くなるのにつれて，岩石・鉱物からの， ラドンのエマ ネーション化は減少する。大気中に放出されるラドン も少なくなり，地上でのラドンとカリウム成分との相 関性は快復傾向を辿る。

四 9 は地殼変動域での大気中のラドン分布と, 地上 でのラドンとカリウム成分の相関性との関係を示した ものである。この四から

1）野島地震断層を初めとし地震断層, 震源断層と も本震震源地で, 多量の大気中ラドン分布と,

ラドンとカリウム成分の相関性の悪さが見受け られる

2）野島地震断層を初めとし地震断層, 震源断層と も本震震源地加離れるのにつれて，大気中ラ ドン分布の減少と, ラドンとカリウム成分の相 関性の快復が起こる

3 ）最新の地震断層である野島地震断層を, 大気中 のラドン分布が等価のなかで，他の断層類と比 較するとき，地上でのラドンとカリウム成分の 相関性が格別に低くなっている

ことが明らかで，上述の推論の正しさが裏付けられて いる。

\section{3 地震前後におけるラドン移動}

地款では，地中応力が静かに，時間をかけて，付加
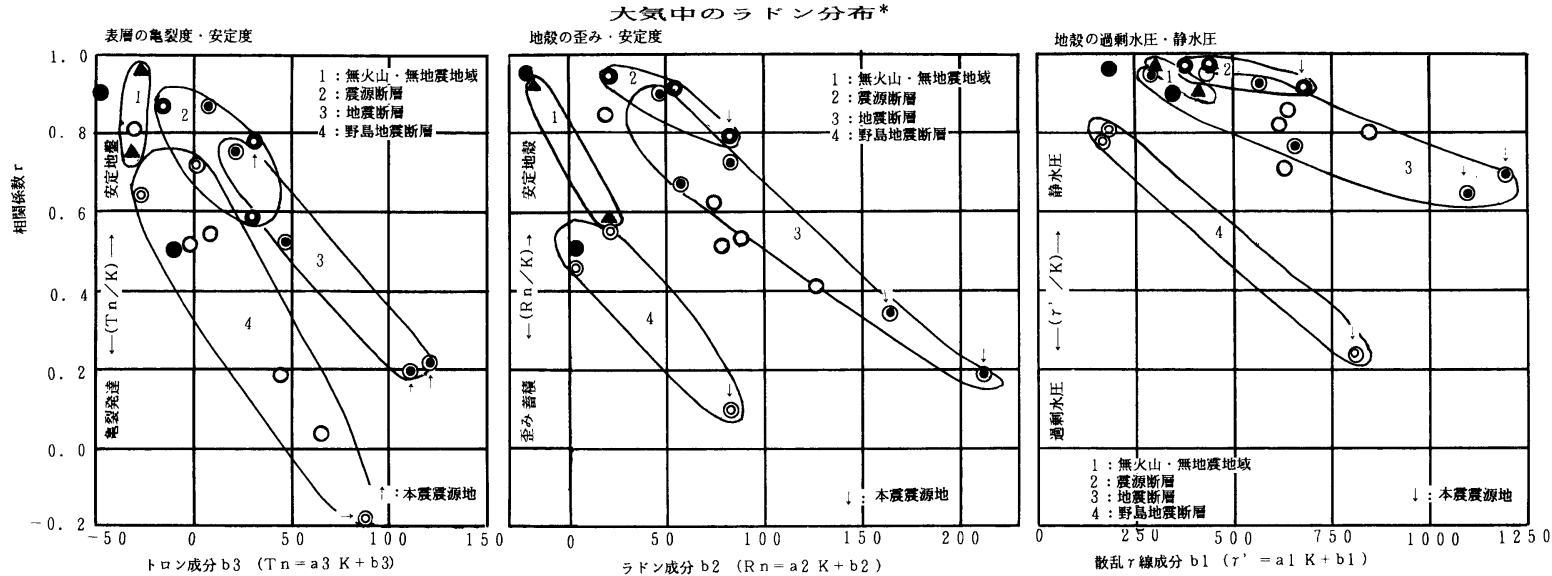

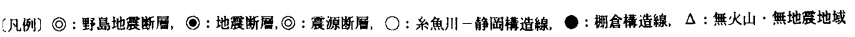


され，歪みが蓄積されていく。そのために地層間隙水 は過剩水圧状態になることもなく排水され，地中応力 は岩石・鉱物間の応力に転化していく。この過程では, 岩石・鉱物中の空隙は縮小し, ラドン・エマネーショ ンの移動が抑止される。この地域での大気中のラドン 分布は減り, 地上でのラドンとカリウム成分の相関性 が良くなる。更に地中応力の蓄積が進むと，岩石・鉱 物においては外部応力に耐之きれなくなって, 部分的 な破壊が進行しはじめる。そのような状態になると， エマネーション化とラドン・エマネーションの移動が, 再度, 進行しはじめる。大気中のラドン分布も増之は じめ，地上でのラドンとカリウム成分の相関性が落ち る。

岩石・鉱物の破壊が全面的に広がり，そこを本震震 源地とした地震発生に至る過程に対応して, 大気中の ラドン分布は激増し，地上でのラドンとカリウム成分 間の相関性が極端に悪化する。破壊面が拡大する過程 で, 地下水の破壊面への浸入が併行して進行し, ラド ン・エマネーションの移動は抑制され, 大気中のラド ン分布が減る。そして, 本震震源地での地震発生とな る。

地震発生以降, ほぼ逆工程を経て地震発生前の状態 に長年月かけて復帰する。

図10は地震後における地盤・地壳の安定化の状況を 既存の地震断層から見たものである。図 9 と重るて見 ると

1) 地上の散乱 $\gamma$ 線成分とカリウム成分の相関性 から地殼の水圧状態をみると, 地震後の時間経 過と共に正常状態に復帰する傾向が見られる

2) 地上のラドン成分とカリウム成分の相関性から 地壳の歪み状態をみると, 地震後の時間経過と 共に正常状態に復帰する傾向が見られる

3 ）地上のトロン成分とカリウム成分の相関性から 表層の亀裂度・安定度をみると, 地震後の時間 経過と共に正常状態に復帰する傾向が見られる ことが明らかで, 上述の推論の正しさが裏付けられて いる。

\section{6. 淡路島北部でのモデル検証}

\section{1 検証 1 （本震震源地と大気中のラドン分布）}

明石海峡の梁さ約 $14 \mathrm{~km}$ に本震震源を持つ兵庫県南 部地震 M7.2 では, 淡路島北端で, 大気中のラドン分布
大気中のうドン分布

(活断包)

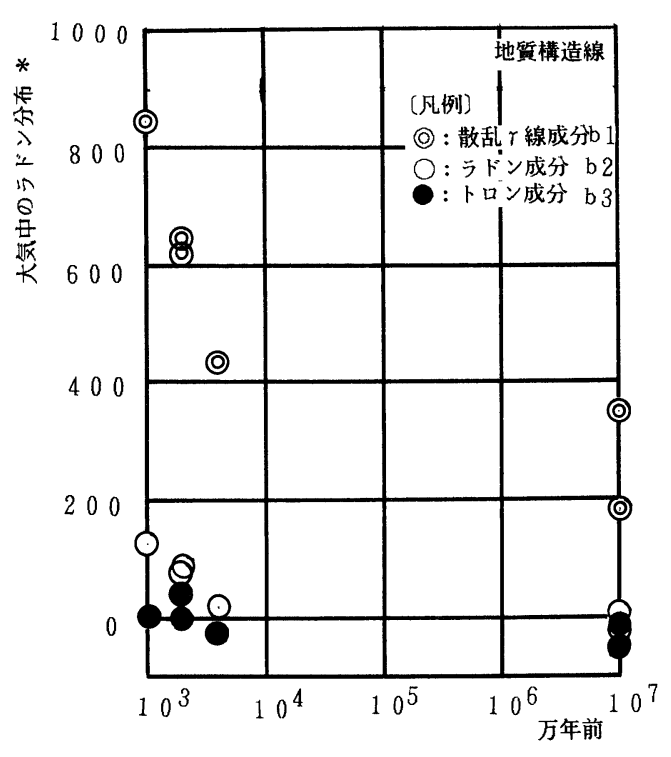

*： 5 仁 N a I シンチレータ 8 本による空中観測 5 秒間カウント数

図10＼cjkstart地震後における地盤・地殼の安定化とラドン

が格別に多く, 地盤・地殼の変動が激しかった，と予 測される。図11は阪神大地震後の淡路島北部上空での ラドン分布を示したものである。この図から

1) 本震震源地から最も近い測線, 特に西側域の上 空で, ラドンの各成分（散乱 $\gamma$ 線・ラドン・ト ロン）が格段に大きなものになっている

2 ) 本震震源地から最も近い測線, 特に西側域の地 上ではカリウム成分と, 散乱 $\gamma$ 線, ラドン, ト ロンの各成分間の相関性が極めて悪く, トロン 成分においては負相関になっている。地盤・地 殼の変動が極めて激しかった

ことは明らかで，上述の予測が検証できる。

\section{2 検証 2 (野島地震断層と大気中のラドン分布)} 活断層の野島断層が兵庫県南部地震で動き, 野島地 震断層からのラドン・エマネーションの放出が予測さ れる。特に地表付近の地盤変動では散乱 $\gamma$ 線成分とト ロン成分が関与する。西側の海岸線近くを通る, 地震 断層を包括する北淡町では, 淡路町・東浦町よりも, 大気中のラドン分布（散乱 $\gamma$ 線成分・トロン成分）が 多く, また地上ではカリウム成分と, 散乱 $\gamma$ 線, トロ ンの各成分との相関性が落ち込んでいる, と予測され る。図11は阪神大地震後の淡路島北部上空でのラドン 


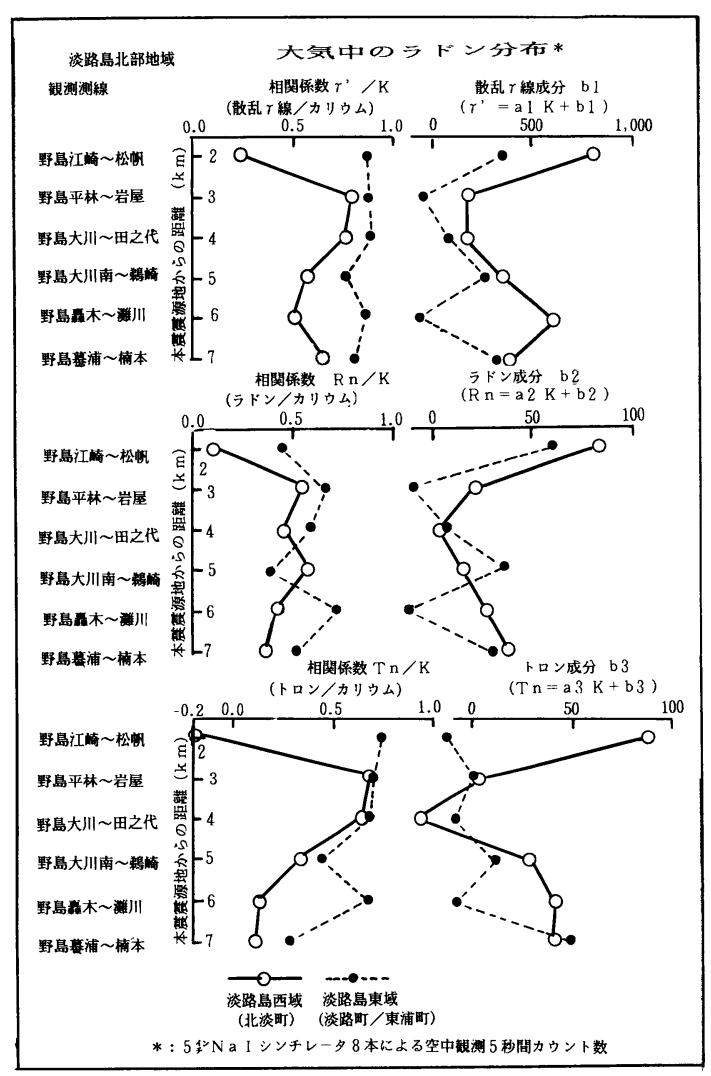

図11 阪神大地震後の淡路島北部上空でのラドン分布

分布を示したものである。この四から野島断層を包括 する淡路島北部西域の北淡町では, 淡路町・東浦町よ $\eta$ 毛

1) 大気中のラドン分布（散乱 $\gamma$ 線成分・トロン成
分）が多くなっている，また

2 ）地上ではカリウム成分と, 散乱 $\gamma$ 線, トロンの 各成分との相関性が落ち込んでいる ことは明らかで，上述の予測が検証できる。

6.3 検証 3 (断層変位とラドン・エマネーション) 地壳変動では岩石・鉱物からのラドン・エマネーショ の移動が進行し, 地震断層から放出されるラドン・工 マネーションも多くなる。その際, 地殼変動の規模が 大きなものだと, 断層面が地上に現れ, 地震断層になっ て, 地表に変位をもたらす。従って, 地震断層の上空 域において観測される大気中のラドン・エマネーショ ン $\left(\Delta \gamma^{\prime}, \Delta \mathrm{Rn}, \Delta \mathrm{Tn}\right)$ にあっては，断層変位との相関 性が高くなる。特に地盤変動との関連性の強いトロン 成分 $\Delta \operatorname{Tn}$ において，その傾向が顕著になる，と予測さ れる。図12は野島地震断層の変位量と, 断層上空域で のラドン・エマネーションとの関係を示したものであ る。この図から

1）野島地震断層の最大変位が現れている地域で は, ラドン・エマネーションも多くなっている

2 ）野島地震断層での変位はトロン成分 $\Delta T n$ と高 い相関性が見られる

ことは明らかで，上述の予測が検証できる。

\section{7. $\gamma$ 線リモートセンシングによる地震予知 法の提言}

内陸型地震予知のために下記の観測手法が有効であ ると判断し, 以下の提言をしたい。

(1) 大気中のラドン分布の航空機観測

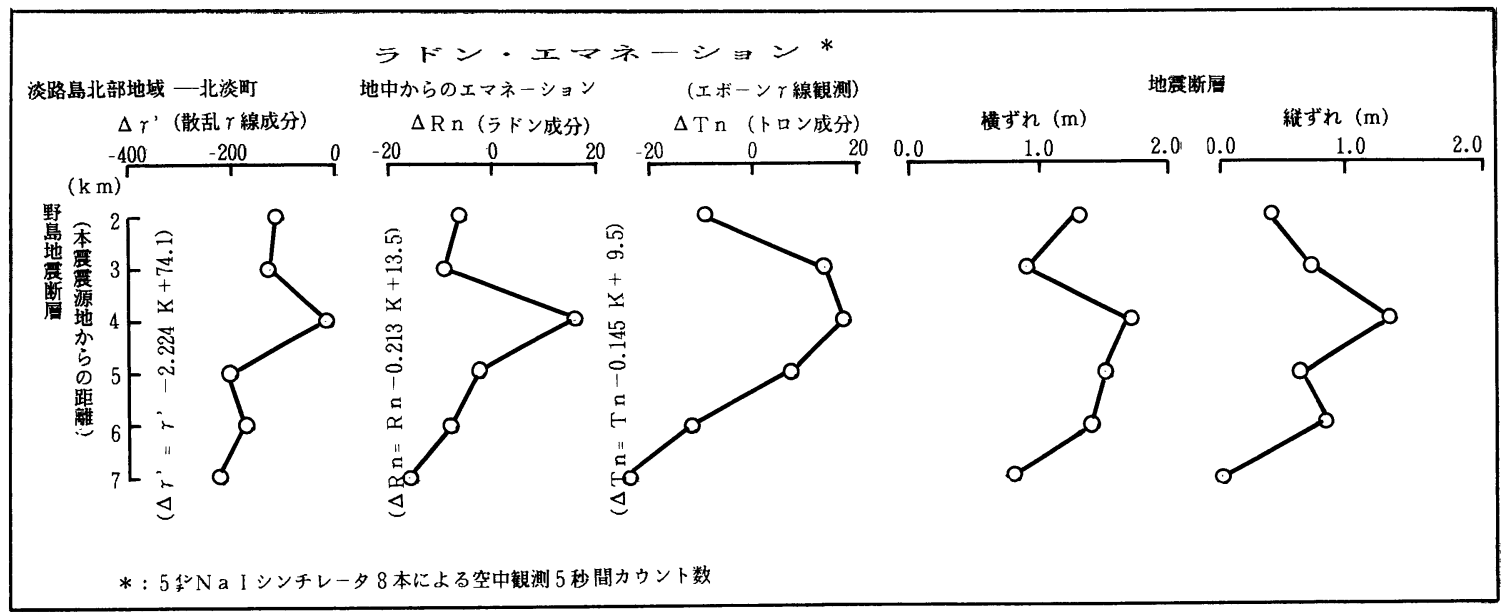

図12 野島地震断層の変位量と断層上空のラドン・エマネーション量 
年 1 回以上，エアボーン $\gamma$ 線スペクトロメトリを実 施し, 対象地域の大気中のラドン分布を観測する。こ れは国家機関で実施されるのが適切であろう

(2) ラドン・エマネーションの走行連続観測

月 1 回程度, 走行自動車からの $\gamma$ 線スペクトロメト リを実施し，市町村域のラドン・エマネーションを観 測する。これは自治体で実施されるのが適切であろう

(3) ラドン・エマネーションの固定連続観測

観測強化地域では固定観測点を設定し，24時間連続 で，ラドン・エマネーションの観測を実施する。これ は国家機関で実施されるのが適切であろう

（4）測地・地震情報との連動評価

国家機関での情報の総括を基本原則とし，ここで得 られた大気中のラドン分布, 地中からのラドン・エマ ネーション, 並びにラドン変動の要因となった地盤・ 地款変動情報を, 既存の測地・地震情報に加え, 専門 家による地震予知判定の材料とする

\section{参考文献}

1）荒木春視（1983）へリコプターによるリモートセンシ ングー熱赤外線およびガンマ線の利用一, 写真測量とリ モートセンシング, Vol.22, No.3, 34-44

2) 荒木春視 (1987) 超低空からのリモートセンシング技
術，写真測量とリモートセンシング，Vol.26, No.3, $31-42$

3 ）中村一明・松田時彦 - 守屋以智雄（1987）火山と地震 の国，岩波書店発行

4) 荒木春視 (1990) $\gamma$ 線りモートセンシング一地上デー夕 の収集一, 写真測量とリモートセンシング, Vol.29, No.4, 24-41

5 ) 活断層研究会 (1991) 新編 日本の活断層一分布困と 資料一, 東京大学出版会発行

6 ) 荒木春視・杉浦邦朗 (1993) エアボーン $\gamma$ 線スペクト ロメトリ（I），写真測量とリモートセンシング， Vol. 32 , No.1, 36-43

7 ）荒木春視・杉浦邦朗（1993）エアボーン $\gamma$ 線スペクト ロメトリ（II）, 写真測量とリモートセンシング, Vol. 32 , No.2, 25-37

8 ）荒木春視 (1994）エアボーン・ラドンエマノメトリー ラドン・エマネーションの測定一, 写真測量とリモート センシング, Vol.33, No.4, 32-57

9 ）荒木春視（1995）リモートセンシング，最新地盤調査 ハンドブック，417-438，建設産業調査会発行

10）佐伯雄司ほか（1995）兵庫県南部地震前後の西宮にお ける地下水中ラドン濃度の変動, 第 32 回理工学におけ る同位元素研究発表会要旨集, p.158

11）吉田明夫（1995）1995 年兵庫県南部地震, 地質 ニュース, No.486, p.8

12）粟田康夫ほか (1995) 1995 年兵庫県南部地震に伴っ て出現した地震断層, 地質ニュース, No.486, p.16 